\title{
The Influence of Psychographic Variables on the Theory of Exit, Voice, and Loyalty of Customer Complaints Behaviour in Banks
}

\author{
- Preko Alexander, Agbanu Kwami Samuel
}

\begin{abstract}
This paper analyses Customer Complaints Behaviour (CCB) using psychographic factors and the Theory of Exit, Voice and Loyalty. Prior studies on the continent of Africa have explored customer dissatisfaction, service failure, complaints handling and complaint attitudes, but not in association with psychographic factors. This research gap is addressed with a new conceptual understanding that integrates psychographic variables and the Theory of Exit, Voice and Loyalty in a single study. In total, 171 valid questionnaires were gathered from customers of two public banks in Accra chosen randomly, and a convenience sampling method was used for the respondents. This study has revealed that assertiveness, conservatism, attitude towards complaints, sense of justice, service attribute significantly influence the theory of Exit, Voice and Loyalty of CCB. What is more, the findings have also shown that there is a statistical difference between complainers and non-complainers. Complainers are more likely to stay loyal, and are less likely to voice out or leave their bankers. We suggest that banks should not only center CCB strategies towards complainers, but should also take into account non-complainers as they are equally important to businesses.
\end{abstract}

Keywords: Complaints, Behaviour, Attitude, Exit, Voice, Loyalty, Psychographics Factors JEL Classification: M00, M10, M31

\section{INTRODUCTION}

Customer Complaints Behaviour (CCB) is one great area that has received great attention from researchers (Day \& Landon, 1997; Onyeaso, 2007; Atalik, 2007) in the Western world, and (Liu \& McClure, 2001; Hui \& Au, 2001; Heung \& Lam, 2003; Kim, Kim, Im \& Shin,2003; Phau \& Sari, 2004; Ndubisi \& Ling, 2006; Kau \& Loh,2006) in Asia. The findings of their studies have significantly contributed to the existing CCB literature available for researchers and practitioners. In Africa as well as Ghana, Customer Complaints Behaviour is understudied, as few researchers like (Donoghu \& De Klerk, 2006; Petzer \& Moslert, 2012; Iyiola \& Ibidunni, 2013; Nimako \& Mensah, 2014; Ofori-Okyere \& Kumadey, 2015) have studied CCB on the continent. The few studies conducted on the continent not moved beyond, improving of the customer complaints and loyalty in the telecommination sector, Uganda (Komunda, Kibeera, Munyoki \& Byarugaba, 2015), exploring customer dissatisfaction/satifaction and complaining responsess among bank customers, Ghana (Nimako \& Mensah, 2014), dissatisfaction and complaining responses towards mobile telephony service, Ghana (Mensah \& Nimako, 2012), complaints behaviourand product failure, South Africa (Donoghu \& De Klerk, 2006) complaints emotion, anger, and subsequent behaviourof customers, Nigeria (Iyiola \& Ibidunni, 2013) service failure and customer 
compalints management in the health sector, Ghana (Ofori-Okyere \& Kumadey, 2015), attitude towards and likelihood of complaining in the banking, domestic airline and restaurant industry (Petzer \& Moslert, 2012). It is obvious that, little has been studied on how psychographic variables: justice of success, self-confidence and willingness, conservatism, assertiveness, attitude towards complaints, and attitude towards businesses in general influence complaints CCB of (complainers and non-complainers) based on the three characteristics of Hirschman's theory (1970): Voice, Exit and Loyalty. This gap is addressed by testing the relevance of Hirschman's theory and conceptualising CCB by applying the psychographic factors in competitive Ghanaian banking environment.

Previous studies have attempted to explore the relationship between psychographic variables (neuroticism) and CCB as indicated by (Mooradian \& Olver, 1994). These researchers further explained that neoroticism infleunces directly and indirectly the probability of a customer to complain or not. It is obvious to see highly self-confiedent customers to complain more frequently due to their personalilty. Landon (1980) found out that the complaints come as a result, of dissatisfaction on the part of the customer, when he or she perceives complaint as a negative issue. However, Hirschman (1970) argued that when customers decide to complain they positively value between the balance of costs and benefits. Both costs and benefits are not only economic, but also psychological as indicated by (Hirschman, 1970). Some customers of the banks might not complain because they perceive the benefit might not be big enough.

On the contrary, Lui, Bai and Zhang (2006) identified that even some satisfied customers might still complain in order to provide useful feedback on the product or the service to the providers on service quality. Complaints reveal problems that are significant and deserve the attention of businesses. Sanes (1993) found out that complaints could, inform retailers and manufacturers about consumers' current needs and provide solutions for discussion of future needs. Then how are banks in Ghana utilizing customer complaints to satisfy, retain and develop the customers? Customer complaints could serve as a competitive tool used by any bank to increase satisfaction.

According to the Ghana Banking Survey Report of 2013, there are 26 licensed banks in Ghana. The statistics presented by the Bank of Ghana's Annual Report (2010) registered 170 customer complaints. Issues addressed included non-payment of dividends and interests, high interest rate, high bank charges and fraudulent withdrawals. Wysocki, Kepner and Glasser, (2001) in their studies showed that despite bank made the efforts in providing quality service to the customers in order to achieve satisfaction and loyalty, the fact remains that no organization is so perfect in the delivery of superior service that do not have any level of dissatisfaction to the customer. This study is necessary in addressing CCB due to the influx of both international and local banks in the Ghanaian economy, which has brought about fierce competition in banking services or products allowing customers to have a choice.

Furthermore, studies have established the fact that some dissatisfied customers may not voice out their complaints, but might use other channels such as negative word-of- mouth, aggression, taking the business to a competitor among others (Cheng, Lam \& Hsu, 2001; Cho et. al., 2002; Wysocki, Kepner \& Glasser, 2001). Then how would banks in developing countries use customer complaints behaviour as competitive advantage? Therefore, the paper endeavors to achieve three 
objectives. Firstly, to find out whether there are statistical differences between complainers and non-complainers based on their psychographic factors, secondly to predict the probable CCB of complainers and non-complainers in relation to the theory and finally to investigate the effects of psychographics factors on Hirschman's theory.

\section{LITERATURE REVIEW}

\subsection{Customer Complaints Behaviour}

There have been various definitions of Customer Complaint Behaviour (CCB) over the years. This has brought about a diverse understanding of the concept but majority of these definitions tried to identify behavioural or non-behavioural responses caused by a service or product failure or customer dissatisfaction. The theme for this study mainly focused on Exit, Voice and Loyalty theory, which is operationalized as CCB. Jacoby and Jaccard (1981) argued that CCB is an action which began by an individual including a communication of something negative about a product or (service), targeted towards either the company or a third entity. However, these researchers Fornell and Wernerfelt (1987) later in the years identified CCB as an attempt to change unsatisfactory situation. Furthermore, Singh (1988) advocates that, CCB is activated at an emotional or sentimental level by a perceived dissatisfaction. In the 21st century, different definitions were merged. Velázquez \& et al, (2010) defined CCB as an emotionally loaded phenomenon where effects are apparent in both the content and the way the complaint is expressed). These researchers further argued that, a complaint is usually understood to be of a cognitive response but most often, it turns out to be an emotional phenomena. This behaviour affects both the context and the way the complaint is expressed. Homburg and Fürst, (2005), referred to CCB as responses triggered by perceived dissatisfaction that is neither psychologically accepted nor quickly forgotten in consumption of a product or service. CCB is a wide range of behavioural as well as non-behavioural responses ranging from taking action in the most situations to prolonged legal action in some cases (Crie, 2003). Then what is the right way of explaining or understanding CCB? It implies that the understanding and application of CCB is widely based on context wise. The application of CCB might also be context wise, where the definition is provided based on the environment.

Well, customers become dissatisfied when their expectations are not met by the current performance of the product or service bought. Generally, customer dissatisfaction is the platforms on which CCB begins. The Expectancy Disconfirmation Theory argued that dissatisfaction leads to $\mathrm{CCB}$ as a result of the gap between customers' expectation and the actual performance of the product or service (Oliver, 1980). Most studies on CCB confirmed that consumer dissatisfaction could originate based on several aspects of the consumption process, like the product itself, customer service, store atmosphere, and warranty, (Crie, 2003; Bearden \& Oliver, 1985; Day \& Landon, 1976). Understanding CCB is important in today's business because effective CCB management might serve as a competitive advantage as stated by (Azml, Zarina, \& Nur, 2015). 


\subsection{Theory of Exit, Voice and Loyalty (Hirschman 1970)}

Hirschman's theory of Exit, Voice and Loyalty was first discussed in the context political science. A few decade later, the theory has been widely adopted into management science to study the response behaviour of consumers (Blodgett, Granbois and Walters, 1993; Phau and Sari, 2004; Singh, 1990; Oh, 2003; Ng, 2001) were among others. Hirschman (1970) categorized CCB responses into exit, voice, and loyalty. Exit is an active and destructive response to dissatisfaction, unveiled by a break of relationship with the object (brand, product, retailer, supplier, or service provider). Voice is a verbal and constructive response with an expectation of change in the organization's practices, policies, and responses; this is commonly addressed towards friends, relative, etc. Hirschman (1970) stated that when customers decide to complain, they positively value between balance of costs and benefits. Both costs and benefit are not only economic, but also psychological as indicated by Andreasen (1970). Sometimes, the perceived benefit might not be great enough to lead a consumer to lodge complaint, even if significant dissatisfaction exists.

On the contrary, Day and Landon, (1977) claimed that a customer might go ahead to complain even with a low level of dissatisfaction, if the perceived benefit is remarkable. Understanding CCB might be considered imperative for organizations like banks in probing why a customer chooses a specific complaints behaviour. In so doing, the bank might develop complaint programmes or strategies to manage the fierce competition in the industry. Managing complaints behaviour cannot be omitted from organizational strategies; therefore, studying of CCB in a developing country is equally important to the sustainability of businesses.

However, these studies (Cheng, Lam \& Hsu, 2001; Wysocki, Kepner \& Glasser, 2001; Cho et. al., 2002; Donoghu \& De Klerk, 2006; Ofori-Okyere \& Kumadey, 2015: Iyiola \& Ibidunni, 2013) have come to recognize the contributions of Hirschman's Theory of Exit, Voice and Loyalty to the study of CCB worldwide. The theory hypothesizes that customer complaint behaviour depends on the value of voicing the complaint, the probability that the complaint will be successful, and on the ability and willingness to take up the voice, and that exit is often a last resort (Blodgett et.al, 1993).

Well, the theory was used to explain why some dissatisfied consumers complain to their sellers (voice) while others might slightly vow to never do business and move their businesses elsewhere (exit). For example, he also utilized the theory to describe organizations where employees who are not satisfied would leave, while others stay, even in the presence of better job opportunities (these latter employees are loyal). This situation might be the same in Ghana, where some dissatisfied consumers of the banks would exit, others would voice out seeking redress and some would stay loyal to their bankers. In this competitive era, how would a bank handle customers who resort to exiting the bank or continue to complain due to service failure? Based on the discussion above, it is hypothesized that

$\mathrm{H}_{1 \mathrm{~A}, \mathrm{~B}, \mathrm{C}}$ : There is a statistical difference between complainers and non-complainers of voicing $\left(\mathrm{H}_{1_{\mathrm{A}}}\right)$, exiting $\left(\mathrm{H}_{:_{1 \mathrm{~B}}}\right)$, and staying loyal $\left(\mathrm{H}_{1_{1 \mathrm{C}}}\right)$.

$\mathrm{H}_{1 \mathrm{D}, \mathrm{E}, \mathrm{F}}$ : There is a statistical difference between complainers and non-complainers of selfconfidence and willingness $\left(\mathrm{H}_{:_{1 \mathrm{D}}}\right)$, conservatism $\left(\mathrm{H}_{:_{1 \mathrm{E}}}\right)$, and assertiveness $\left(\mathrm{H}_{\mathrm{1F}_{\mathrm{F}}}\right)$, of CCB. 
H2: There is a statistical difference between complainers and non-complainers of stopping to do business with the bank.

$\mathrm{H}_{2 \mathrm{~A}, \mathrm{~B}, \mathrm{C}}$ : The probability of customers to voice out $\left(\mathrm{H}_{2 \mathrm{~A}}\right)$ or exit $\left(\mathrm{H}_{2 \mathrm{~B}}\right)$, or stay loyal $\left(\mathrm{H}_{2 \mathrm{C}}\right)$ is more likely among complainers than non-complainers.

\subsection{Demographic Characteristics}

Marketing literature has proved that consumer's characteristics are importance of CCB to businesses. These characteristics include cultural, education, age, income, gender (Sujithamrak \& Lam, 2005; An, Hui, \& Leung, 2001; Liu \& McClure , 2007). However, earlier literature on CCB supported the notion that demographics variables have been found to be the antecedents of CCB (Jacoby \& Jaccard, 1981; Bearden \& Oliver, 1985; Richins,1987; Singh, 1990).

$\mathrm{H}_{2 \mathrm{D}}$ : The probability of customers towards $\mathrm{CCB}$ is more likely to be influenced by gender among complainers.

\subsection{Product Attributes}

One main component that triggers customer dissatisfaction is product or service attributes. Product attributes associated with CCB included the nature of the product or product category (Kincade et al, 1988) cost of the product (Day \& Landon, 1977) and the importance of the product to the consumer (Stephens \& Gwinner, 1998; Sheth, Mittal, \& Newman, 1999). Gilly \& Gelb, (1982) cited in (Donoghue \& De Klerk, 2006) also discussed durabilty of the product as additional of product attribute in their studies. Phau and Sari, (2004) found out that consumers often make decisions to purchase based on the price. Keng, Richmond, and Han, (1995) further identified that consumers were likely to complain when there was an increase in the price of products or service that they purchase frequently. Consumers also tend to associate high quality to a product based on the perceived high price of the service or the product. Day (1977) confirmed the higher the price of a product or service, the higher the expectations to perform well. He further explained that consumers would probably complain if the actual performance of product dilutes their status. In the Ghanaian-banking environment, customers access these services: savings, deposit, fixed deposit, transfer of cash within organizations, or personal use and other payments. If any of these services are diluted that could lead to dissatisfaction.

$\mathrm{H}_{3}$ : Product attributes significantly influence the Ghanaian CCB.

\subsection{Attitude Towards Complaints and Business in General}

Customer attitude towards complaining largely depends on the personal tendency of a dissatisfied customer who seeks compensation from the firm (Yuksel \& Kilinc, 2006 cited in Mousavi \& Esifidani, 2013) comprehensive model of CCB). According to Fishbein and Ajzen (1975), attitude can be examined as how a person generally sees a specific behaviour negatively or positively, after assessing the results of the act. Other researchers like Blodgett, Wakefield and Barnes, (1995, in Norazah, 2010) explained attitude towards complaining as an individual's disposition to rectify the problem when he or she is dissatisfied with a product or service. In the Ghanaian environment, some customers would always evaluate the cost and benefit associated with 
complaining before he or she makes the effort to lodge a complaint. This behaviour is similar to the findings of (Hirschman 1970; Richins 1980), who argued that customers' perception to complaint depends on the costs and the benefits. Literature on CCB has proved that customers who do not complain involve in negative behaviour like taking their businesses to other competitors or speak negative words-of-mouth against the organization (Blodget \& Granbois, 1992). Analyzing from the literature above it is hypothesized that:

$\mathrm{H}_{4}$ : Attitude of Ghanaian consumers of the banks toward complaints significantly influence CCB.

Attitude towards businesses in general is one main component of CCB. This variable as defined by Singh and Wilkes, (1996) as an individual's feelings about the marketplace, the behaviour of firms and the consumption of products and services. Is there any relationship between customers' attitude toward businesses in general and CCB? Researches have established that there is a positive and significant relationship between responsiveness and complaining (Richins \& Verhage, 1985; Lau \& Ng 2001). However, this was in contrast to the study of Barnes and Kelloway, (1980), who discovered that attitude towards businesses, had a more negative towards complaints behaviour. Building from the preceding discussion it is hypothesized that:

$\mathrm{H}_{5}$ : Attitude of Ghanaians towards banking businesses in general significantly influence CCB.

\subsection{Psychographics (Self-Confidence and Willingness, Conservatism, Assertiveness, Success of Justice)}

Psychographic factors examined in this study are sense of justice, self-confidence, assertiveness, conservatism, attitude towards businesses in general, and attitude towards complaining. According to Homer and Kahle (1988) psychographic characteristics determine human behaviour. Morganosky and Buckley (1984) confirmed that traits such as uniqueness and individuality and sense of independence affect Customer Complaint Behaviour. Davidow and Dacin, (1997) showed that psychographic factors like personality and attitudes are the reasons that influence customer complaints behaviour, and different people will show different responses when they face dissatisfactory situations. People are more likely to complain if they perceive complaining as an appropriate behaviour.

Phau and Sari (2004), pointed out that, some people do not hesitate to voice out their dissatisfactions if other possibly show negative responses to complaints behaviour. Lau and $\mathrm{Ng}$ (2001) also found out that, generally, customers who complain are more likely to be self-confident and socially responsible. Socially responsible people tend to complain because they believe others would benefit from the complaints. Self-confidence as defined by Coopersmith, (1967) refers to an individual's belief of his/her overall competence. However, Bearden and Mason (1984) identified that complaints handling attitude is associated to assertiveness and feelings of powerlessness. Galassi and Galassi (1977) defined assertiveness as behaviour emitted by a person in an interpersonal context. These behaviours exhibit person's feelings, attitudes, wishes, opinions, and honest while respecting the feelings, attitudes, wishes and rights of others. Consumers who complain are more assertive and able to stand up for their rights (Fornell and Westbrook, 1979). 
Singh (1990) observed that perceived success of justice in complaint behaviour is the likelihood of getting redress or apology when customers lodge complaints with a company. Customers to some extent complain when they know their complaints would be valued indicated by (Rizwan, Ahmed \& Nazeer, 2013). Researches of (Morel, Posez \& Wilke, 1997; Singh, 1990; Day \& Landon 1976) showed that customers become more likely to lodge complaints when they identify high value of complaining, rather than getting involved in any other response.

$\mathrm{H}_{6}$ : Self-Confidence and Willingness $\left(\mathrm{H}_{6 \mathrm{~A}}\right)$, Assertiveness $\left(\mathrm{H}_{6 \mathrm{~B}}\right)$, Conservatism $\left(\mathrm{H}_{6 \mathrm{C}}\right)$ Sense of Justice $\left(\mathrm{H}_{6 \mathrm{D}}\right)$, Attitude Towards Complaints $\left(\mathrm{H}_{6 \mathrm{E}}\right)$ Attitude Towards Business in General $\left(\mathrm{H}_{6 \mathrm{~F}}\right)$ Service Attributes $\left(\mathrm{H}_{6 \mathrm{G}}\right)$ positively influence customer to voice out in the Ghanaian Banking Environment.

$\mathrm{H}_{7}$ : Self-Confidence and Willingness $\left(\mathrm{H}_{7 \mathrm{~A}}\right)$, Assertiveness $\left(\mathrm{H}_{7 \mathrm{~B}}\right)$, Conservatism $\left(\mathrm{H}_{7 \mathrm{C}}\right)$ Sense of Justice $\left(\mathrm{H}_{7 \mathrm{D}}\right)$, Attitude Towards Complaints $\left(\mathrm{H}_{7 \mathrm{E}}\right)$ Attitude Towards Business in General $\left(\mathrm{H}_{7 \mathrm{~F}}\right)$ Service Attributes $\left(\mathrm{H}_{7 \mathrm{G}}\right)$ positively influence customer to exit the Bank.

$\mathrm{H}_{8}$ : Self-Confidence and Willingness $\left(\mathrm{H}_{8 \mathrm{~A}}\right)$, Assertiveness $\left(\mathrm{H}_{8 \mathrm{~B}}\right)$, Conservatism $\left(\mathrm{H}_{8 \mathrm{C}}\right)$ Sense of Justice $\left(\mathrm{H}_{8 \mathrm{D}}\right)$, Attitude Towards Complaints $\left(\mathrm{H}_{8 \mathrm{E}}\right)$ Attitude Towards Business in General $\left(\mathrm{H}_{8 \mathrm{~F}}\right)$ Service Attributes $\left(\mathrm{H}_{8 \mathrm{G}}\right)$ positively influence loyalty in the Ghanaian Banking Environment.

\section{RESEARCH METHODOLOGY}

\subsection{Research Design and Data Collections}

The study utilized survey and correlational designs as well as a quantitative approach to evaluate participants' responses and identify relationships between the factors: exit, voice, and loyalty and psychographics' influence on CCB in the Ghanaian banking environment. We chose these designs survey, correlational and quantitative approach because information was gathered through questionnaires and the variables were quantified and tested to establish relationships.

The questionnaires consisted of two sections, where the first section examined the elements of Hirschman's theory and psychographic factors: attitude towards complaints, sense of justice, service or product attribute, attitudes towards business in general, self- confidence and willingness, conservatism and assertiveness. The explanation of the Hirschman's 1970 theory provided in the study of (Blodgett, Granbois \& Walters, 1993) was adapted to develop CCB questions in the first section. The questions in the first section were measured on a five-Likert scale point, ranging from 1 strongly disagree to 5 strongly agree. In all they were 33 instruments of which 28 were in the first section and 5 were in the second section. Because the attribution constructs were formulated as a formative measure, the responses of these items were summed after reverse scoring so that higher values mean the respondents strongly agreed to the statement. Out of the 28 questions, the study borrowed 20 questions out of 40 psychographic questions from the work of (Phau \& Sari, 2004) and revised it for the Ghanaian banking context. Voice, exit and loyalty were adapted from the previous study (Norazah, 2010) as CCB. The second section of the questionnaire contained demographic information like gender, age group, level of education, income level and complaint status (complainers or non-complainers). 


\subsection{Sampling}

The target population was all customers of two branches each of two public banks in the capital. The banks selected were randomly sampled through the balloting approach. The rational for adopting random sampling method was because complaint is a common characteristic of service or product failure in any banking sector. One hundred and seventy one (171) respondents were used for this research. The sample size of 171 is adequate for this study because, according to Sekaran (2000) indicated that a sample size of 30 and above 500 respondents is appropriate for a study. This paper applied the convenience sampling technique, where the questionnaires were administered with the assistance of two National Service Personnel in each of the two branches. Questionnaires administered to the customers in the banking halls after they have completed their transactions and were free to answer the questions. For the purpose of accuracy and also to avoid sampling the same respondent twice, the National Service Personnel were educated on to ask customers whether they have already filled this questionnaire for before given it out. Permission was obtained from the branch managers to conduct the survey.

\section{DATA ANALYSIS}

\subsection{Validity and Reliability}

In this paper, the mean, standard deviation, confirmatory factor analysis and reliability test were conducted to describe that data.

Tab. 1 - Mean, Standard Deviation, Validity and Reliability Analysis, Source: Researchers' Calculation, 2015

\begin{tabular}{|l|c|c|c|c|c|}
\hline Variables & $\begin{array}{c}\text { Number } \\
\text { of items }\end{array}$ & $\begin{array}{c}\text { Cronbach } \\
\text { Alpha }\end{array}$ & $\begin{array}{c}\text { Factor } \\
\text { Loading }\end{array}$ & $\begin{array}{c}\text { Mean } \\
\text { (SD) }\end{array}$ & $\begin{array}{c}\text { Std. } \\
\text { Deviation }\end{array}$ \\
\hline Self-Confidence and Willingness & 2 & 0.673 & 0.656 & 2.578 & 1.083 \\
\hline Assertiveness & 2 & 0.667 & 0.758 & 1.147 & 0.471 \\
\hline $\begin{array}{l}\text { Attitude Towards Business in } \\
\text { General }\end{array}$ & 2 & 0.786 & 0.823 & 3.228 & 1.205 \\
\hline Conservatism & 2 & 0.718 & 0.712 & 3.127 & 1.196 \\
\hline Sense of Justice & 3 & 0.671 & 0.750 & 3.044 & 0.974 \\
\hline Service Attributes & 3 & 0.652 & 0.628 & 2.418 & 1.068 \\
\hline Attitude Towards Complaints & 4 & 0.738 & 0.874 & 3.553 & 1.357 \\
\hline
\end{tabular}

Table 1 reveals that all the items measuring psychographic variables had a factor loadings above 0.5 which is the threshold of validity (Hair, Anderson, Tatham, \& Black, 1995). Cronbach alpha values were all above 0.6 supporting the threshold (Nunnally \& Bernstein, 1994) meaning that there is an internal consistency in the instruments used. The highest mean value obtained was 3.553 revealing that customers agreed that they had an attitude towards complaints where there is services failure. However, the least mean value was 1.147 confirming that customers were not bond enough to complain to the bank. Thus, it appears that customers develop attitude towards 
complaining but they are not firm enough to complain which might be due to some factors like whether this would offer a unique opportunity to correct problem, and also improve products and services (Cornell, Bleigh, \& Babakus, 1991).

\subsection{Factor Analysis}

A factor analysis was conducted to extract the most valuable psychographic variables for the study.

Tab. 2 - Factor Analysis, Source: Researchers' Computation, 2015

\begin{tabular}{|l|c|c|c|}
\hline \multirow{2}{*}{ Component } & \multicolumn{3}{|c|}{ Initial Eigenvalues } \\
\cline { 2 - 4 } & Total & $\begin{array}{c}\% \\
\text { of Variance }\end{array}$ & $\begin{array}{c}\text { Cumulative } \\
\%\end{array}$ \\
\hline Self-Confidence and Willingness & 1.86 & 26.61 & 26.61 \\
\hline Assertiveness & 1.34 & 19.11 & 45.72 \\
\hline $\begin{array}{l}\text { Attitude Towards Business in } \\
\text { General }\end{array}$ & 1.16 & 16.62 & 62.34 \\
\hline Sense of Justice & 0.84 & 11.96 & 74.30 \\
\hline Conservatism & 0.76 & 10.89 & 85.19 \\
\hline Service Attributes & 0.58 & 8.25 & 93.44 \\
\hline Attitude Towards Complaints & 0.46 & 6.56 & 100.00 \\
\hline
\end{tabular}

Extraction Method: Principal Component Analysis

Table 2 shows the factor analysis. The factor analysis was calculated on the psychographic variables utilizing the principal component method with the varimax rotation. Kaiser-Meyer Olkin (KMO) criterion was adopted where three factors merged explaining $63 \%$ of the variance in the psychographics factors. The three extracted factors, self-confidence and willingness of the customers to complain had accounted for $26.61 \%$, assertiveness $19.11 \%$ and attitude towards business in general $16.62 \%$ of the variation of the factors. KMO value of 0.559 was obtained, and Bartlett's test Sphericity has been conducted with the aim of testing the null hypothesis that the population correction matrix of the variables is an identity matrix. The chi-square statistic is 229.778 and $p$ value is 0.000 indicates that there is correlation of variables to each other, hence the null hypothesis is rejected.

\subsection{Mann-Whitney U - test}

This paper employed Mann-Whitney U non-parametric test to identify whether there is a statistical difference between complainer and non-complainer groups of customers of the bank. 
Tab. 3 - Mann-Whitney U test, Source: Researchers' Calculation, 2015

\begin{tabular}{|l|c|c|c|c|c|c|}
\hline & Voice & Exit & Loyalty & $\begin{array}{c}\text { Self Confi- } \\
\text { dence and } \\
\text { willingness }\end{array}$ & $\begin{array}{c}\text { Conserva- } \\
\text { tism }\end{array}$ & $\begin{array}{c}\text { Assertive- } \\
\text { ness }\end{array}$ \\
\hline $\begin{array}{l}\text { Mann- } \\
\text { Whitney U }\end{array}$ & 2367.000 & 2668.500 & 2466.000 & 1857.000 & 2174.500 & 1373.000 \\
\hline $\begin{array}{l}\text { Wilcoxon } \\
\text { W }\end{array}$ & 3357.000 & 10796.500 & 3456.000 & 2847.000 & 10302.500 & 2363.000 \\
\hline Z & -1.523 & -.446 & -1.305 & -3.323 & -2.226 & -5.096 \\
\hline $\begin{array}{l}\text { Asymp. } \\
\text { Sig. } \\
(2-\text { tailed) }\end{array}$ & .128 & .655 & .192 & .001 & .026 & .000 \\
\hline
\end{tabular}

a. Grouping Variable: Complainer and non-complainer

Table 3 shows the Mann-Whitney U test of compare groups. The two groups (complainers and non-complainers) were compared using the Mann-Whitney $U$ test to confirm whether their views on psychographic factors and Hirschman's theory of exit, voice and loyalty were statistically independent. The results reveal that there is no statistical difference $((\mathrm{U})=2367.000$, $\mathrm{p}>0.05$, between the groups when it comes to voicing, wanting to go elsewhere or exiting ((U) $=2668.500, \mathrm{p}>0.05)$ and loyalty $((\mathrm{U})=2466.000, \mathrm{p}>0.05)$ not supporting $\mathrm{H}_{1 \mathrm{~A}}, \mathrm{H}_{1 \mathrm{~B}}$ and $\mathrm{H}_{1 \mathrm{C}}$.

The outcome of the Mann-Whitney $U$ test again revealed that there is a significant difference between the groups on self-confidence and willingness $((\mathrm{U})=1857.000, \mathrm{p}<0.05)$, conservatism $((\mathrm{U})$ $=2174.500, \mathrm{p}<0.05)$, and assertiveness $((\mathrm{U})=1373.000, \mathrm{p}<0.05)$, supporting $\mathrm{H}_{1 \mathrm{D}}, \mathrm{H}_{1 \mathrm{E}}$, and $\mathrm{H}_{1 \mathrm{~F}}$.

\subsection{Binary Logistic Regression}

Binary logistic regression was calculated to predict the probability of the customer complaints behaviour of complainers and non-complainers in relation to the Exit, Voice and Loyalty theory of Hirschman (1970).

Tab. 4 - Binary Logistic Regression, Source: Researchers' Computation, 2015

\begin{tabular}{|l|l|}
\hline CCB & Odds ratio \\
\hline \multirow{2}{*}{ Voice } & 0.9164599 \\
\cline { 2 - 2 } & $(-1.11)$ \\
\hline \multirow{2}{*}{ Exit } & 0.953109 \\
\cline { 2 - 2 } & $(-0.80)$ \\
\hline \multirow{2}{*}{ Loyalty } & $1.811654 * * *$ \\
\hline \multirow{2}{*}{ Male $=1$} & $(3.50)$ \\
\hline
\end{tabular}




\begin{tabular}{|l|l|}
\hline \multirow{2}{*}{ Female $=0$} & 0.0000 \\
\cline { 2 - 2 } & $()$. \\
\hline \multirow{2}{*}{ Constant } & 1.678269 \\
\cline { 2 - 2 } & $(0.90)$ \\
\hline Observations & 171 \\
\hline Adjusted R ${ }^{2}$ & \\
\hline Log lik. & -74.1701 \\
\hline Chi-squared & 21.6565 \\
\hline $\mathrm{r}^{2}$ & \\
\hline $\mathrm{F}$ & \\
\hline
\end{tabular}

$\mathrm{t}$ statistics in parentheses, ${ }^{*} \mathrm{p}<0.10,{ }^{* *} \mathrm{p}<0.05,{ }^{* * *} \mathrm{p}<0.01$, Marginal effect after logistics voice $=0.0161483$, exit $=-0.0165406$, loyalty $=0.01164$.

Table 4 shows the outcome of the Binary Logistic Regression using gender as a control variable. The dependent variable is binary that is non-complainers were coded as zero (0) and complainers as one (1). The coefficient of voicing complaint is 0.92 times less likely and not significant $(\mathrm{p}<0.05)$ for complainers than non-complainers on service failure in the bank, not supported $\mathrm{H} 2 \mathrm{~A}$. The probability of complainers to exit or stop patronizing service from a particular bank is the coefficient of 0.95 less likely and not significant $(\mathrm{p}<0.05)$ than customers, who complained, not supported H2B. Moreover, loyalty was 1.81 times more likely and significant $(\mathrm{p}<0.05)$ for complainers than non-complainers on service dissatisfaction support $\mathrm{H} 2 \mathrm{C}$. The control variable gender introduced into the model reveals that male customers are more likely to be influenced than female in CCB, supporting H2D. The outcome shows that control variables like gender has a significant effect on CCB. The results of the marginal effect after logistics indicated voice $=0$. 016483, exist $=0.0016$, and loyal $=0.01164$. It implies that $1 \%$ increase in voice affects the probability of complaining by 1.61 , and loyalty by 1.16 while $1 \%$ increase in exit decrease complaining by 1.65 .

\subsection{Multiple Regression Analysis}

Multiple regression analysis was conducted to establish significant relationships between the complaints behaviour (voice, exit and loyalty) and these independent variables (self-confidence and willingness, assertiveness, conservatism, sense of justice, attitude towards complaints, service attributes and general attitude towards business.

Tab. 5 - Influence of antecedent variables on Voice, Source: Researchers' Calculation, 2015

\begin{tabular}{|l|c|c|c|c|c|}
\hline \multirow{2}{*}{\multicolumn{1}{|c|}{ Model }} & \multicolumn{2}{|c|}{$\begin{array}{c}\text { Unstandardized } \\
\text { Coefficients }\end{array}$} & $\begin{array}{c}\text { Standardized } \\
\text { Coefficients }\end{array}$ & \multirow{2}{*}{ S Sig. } \\
\cline { 2 - 5 } & B & Std. Error & Beta & & \\
\hline (Constant) & 5.641 & 1.090 & & 5.173 & .000 \\
\hline Attitude towards complaints & .122 & .045 & .209 & 2.744 & .007 \\
\hline
\end{tabular}




\begin{tabular}{|l|c|c|c|c|c|}
\hline Sense of Justice & .038 & .049 & .063 & .770 & .442 \\
\hline Service Attributes & .166 & .084 & .157 & 1.980 & .049 \\
\hline Attitude towards in General & -.036 & .068 & -.042 & -.533 & .595 \\
\hline Self-Confidence and Willingness & .023 & .047 & .043 & .483 & .630 \\
\hline Conservatism & .266 & .092 & .224 & 2.878 & .005 \\
\hline Assertiveness & .080 & .081 & .085 & .981 & .328 \\
\hline
\end{tabular}

a. Dependent Variable: Voice, $\mathrm{R}=0.336, \mathrm{R}^{2}=0.113, \mathrm{p}=0.06, \mathrm{~F}=2.956$

Table 5 reveals that only these independent variables attitude towards complaints, service attribute, and conservatism had significant relationships $(\mathrm{p}<0.05)$ with customers voicing behaviour in the bank, supporting $\mathrm{H}_{6 \mathrm{C}}, \mathrm{H}_{6 \mathrm{G}}$ and $\mathrm{H}_{6 \mathrm{E}}$. The other hypotheses such as (self-confidence and willingness, $\mathrm{H}_{6 \mathrm{~A}}$ ) (assertiveness, $\mathrm{H}_{6 \mathrm{~B}}$ ), (attitude towards business in general, $\mathrm{H}_{6 \mathrm{~F}}$ ) and (sense of justice, $\mathrm{H}_{6 \mathrm{D}}$ ) are not supported.

Tab. 6 - Influence of antecedent variables on Exit, Source: Researchers' Calculation, 2015

\begin{tabular}{|l|c|c|c|c|c|}
\hline \multirow{2}{*}{ Model } & \multicolumn{2}{|c|}{$\begin{array}{c}\text { Unstandardized } \\
\text { Coefficients }\end{array}$} & $\begin{array}{c}\text { Standardized } \\
\text { Coefficients }\end{array}$ & \multirow{2}{*}{ Sig. } \\
\cline { 2 - 5 } & $\mathrm{B}$ & Std. Error & Beta & & \\
\hline (Constant) & 4.977 & 1.143 & & 4.355 & .000 \\
\hline Sense of justice & .208 & .078 & .277 & 2.673 & .008 \\
\hline Service attributes & .700 & .174 & .531 & 4.033 & .000 \\
\hline Self-Confidence and willingness & .044 & .056 & .067 & .787 & .432 \\
\hline Conservatism & -.070 & .112 & -.047 & -.623 & .534 \\
\hline Assertiveness & -.168 & .095 & -.144 & -1.766 & .079 \\
\hline Attitude towards complaints & .699 & .238 & .324 & 2.939 & .004 \\
\hline $\begin{array}{l}\text { Attitude towards business in } \\
\text { general }\end{array}$ & -.327 & .286 & -.150 & -1.144 & .254 \\
\hline
\end{tabular}

a. Dependent Variable: Exit, $R=0.460, \mathrm{R} 2=0.211, \mathrm{~F}=6.245$,

Table 6 shows that sense of justice, service attributes and attitude towards complaints had significant relationships $(\mathrm{p}<0.05)$ with customers exiting or stopping to transact business with the bank, supporting $\mathrm{H}_{7 \mathrm{D}} \mathrm{H}_{7 \mathrm{G}}$ and $\mathrm{H}_{7 \mathrm{E}}$. The outcome confirms that these independent variables (self-confidence and willingness, $\mathrm{H}_{7 \mathrm{~A}}$ ) (assertiveness, $\mathrm{H}_{7 \mathrm{~B}}$ ) (conservatism, $\mathrm{H}_{7 \mathrm{C}}$ ) (attitude towards business in general, $\mathrm{H}_{7 \mathrm{~F}}$ ) were rejected. 
Tab. 7 - Influence of antecedent variables on Loyalty, Source: Researchers' Computation, 2015

\begin{tabular}{|l|c|c|c|c|c|}
\hline \multirow{2}{*}{ Model } & \multicolumn{2}{|c|}{$\begin{array}{c}\text { Unstandardized } \\
\text { Coefficients }\end{array}$} & $\begin{array}{c}\text { Standardized } \\
\text { Coefficients }\end{array}$ & \multirow{2}{*}{$\mathrm{t}$} & \multirow{2}{*}{ Sig. } \\
\cline { 2 - 6 } & $\mathrm{B}$ & Std. Error & Beta & & \\
\hline (Constant) & 4.977 & .751 & & 6.629 & .000 \\
\hline Attitude towards complaint & .067 & .031 & .152 & 2.168 & .032 \\
\hline Sense of justice & .077 & .034 & .172 & 2.281 & .024 \\
\hline Service attributes & .071 & .058 & .090 & 1.238 & .217 \\
\hline $\begin{array}{l}\text { Attitude towards business in } \\
\text { general }\end{array}$ & .118 & .047 & .181 & 2.506 & .013 \\
\hline Self-Confidence and willingness & -.029 & .032 & -.072 & -.888 & .376 \\
\hline Conservatism & .351 & .064 & .394 & 5.519 & .000 \\
\hline Assertiveness & .171 & .056 & .243 & 3.050 & .003 \\
\hline
\end{tabular}

a. Dependent Variable: Loyalty $\mathrm{R}=0.503, \mathrm{R} 2=0.253, \mathrm{~F}=7.907, \mathrm{p}=0.000$

Table 7 indicates that assertiveness, conservatism, sense of justice, attitude towards complaints, and attitude towards business in general had significant relationships $(\mathrm{p}<0.05)$ with loyalty supporting $\mathrm{H}_{8 \mathrm{~B}} \mathrm{H}_{8 \mathrm{C}} \mathrm{H}_{8 \mathrm{D}} \mathrm{H}_{8 \mathrm{E}}$ and $\mathrm{H}_{8 \mathrm{~F}}$. Self-confidence and willingness, service attributes were significant to loyalty as a component of $\mathrm{CCB}$ not supporting $\mathrm{H}_{8 \mathrm{~A}}$ and $\mathrm{H}_{8 \mathrm{G}}$.

\section{DISCUSSIONS}

Customers of the selected banks participated in the study willingly and the results showed that the objectives of investigating the effects of psychographic factors on Hirschman's Theory was achieved. The findings revealed that in the first regression analysis these variables (attitude towards complaints, service attributes and conservatism) were all significant to customers voicing complaints. The second regression showed that only the sense of justice, service attributes and attitude towards complaints were significant to customer exiting, and attitude towards complaints, service attributes, assertiveness, a sense of justice and attitude towards business in general were significant to loyalty. It is clear from this point that the only psychographic variable that was significant to Hirschman's theory, exit, voice, and loyalty was attitude towards complaints which buttressed the assertion of previous studies of Day and Landon, 1977, Mooradian and Olver, 1994; Lang, Bai and Zhang, 2006, Bearden and Oliver, 1985, Crie, 2003. Customers' attitude towards complaints on banking services were significant at all the levels confirming the argument that customers might still go ahead to complain even with low level of dissatisfaction if the perceived benefit is remarkable (Day \& Landon, 1977). With the increasing and on-going competition in the Ghanaian banking environment, customers are becoming enlightened on their rights to complain. Customers of the bank testified to the assertion that, "I always complain when 1 am dissatisfied because it is my right". This implies that customers would always voice or seek redress when they encounter dissatisfaction. It is an indication of a positive attitude towards CCB in the banking environment of a developing nation. 
However, the findings of this study on service attributes as the second common variable that was significant to both voice and exit supported prior studies of Day and Landon, 1976; Bearden and Oliver, 1985; Kincade et al, 1988; Blodgett, Granbois and Walters, 1993; Crie, 2003; Oh, 2003; Phau and Sari, 2004; as well as Gilly \& Gelb, 1982 in Donoghue and De Klerk, 2006. They agreed that service attributes like cost, price or the nature of the product and durability are important features of the product to the consumer (Stephens \& Gwinner, 1998; Sheth et al 1999). If these attributes are tampered with then some customers might trigger to voice or exit or become disloyal to their bankers.

On the other hand, a sense of justice, assertiveness, conservatism, attitude towards business in general were found to be significant at different levels of CCB. The findings on sense of justice is in line with these previous findings (Day \& Landon, 1976; Morel, Posez \& Wilke, 1997; Singh, 1990; Phau \& Sari, 2004; Rizwan, Ahmed \& Nazeer, 2013) which opined that success of justice in CCB is the likelihood of getting redress or an apology when customers know their complaints would be valuable. Lau and $\mathrm{Ng}$ (2001) and Keng et al. (1995) also found out that generally customers who complain are more likely to be bold and socially responsible that their complaints might benefit others. It is laudable to note that complaint behaviour is common to customers in developing country as well as to those in the western world.

Furthermore, the outcome of the statistical differences between the complainers and noncomplainers confirmed that customers possessed different psychographics that influence their decision to complain. It was revealed that these variables: self-confidence and willingness to complain, conservatism and assertiveness differed among the groups, which established a link between previous findings of Lau \& Ng, 2001; Pharu and Sari, 2004. It is relevant to suggest that psychographic characteristics determine human behaviour is most likely to affect complaint behaviour of customers. Therefore, wherever human beings exist, behaviour formation would be present. The findings revealed that attitude to complain about service failure is present in the developing world as customers are perceived to have value for the money.

Finally, the findings showed that the probability to complain is controlled by gender as male complainers are more likely to show their dissatisfaction as compared to the female complainers supporting the previous works of Sujithamrak \& Lam, 2005; Au, Hui, \& Leung, 2001; Liu \& McClure , 2007. Marketing literature has established the fact that consumer characteristics are important factors in studying customer behaviour (Singh, 1990). It is observed that the probability of customers staying loyal to their bankers and hoping that services would improve is higher among complainers that are in line with the findings of (Phau and Sari, 2004).

\section{CONCLUSION AND IMPLICATIONS}

This study established that Hirschman's theory and psychographics factors are very relevant in the studying of CCB in the banking environment of a developing nation. The proposed Hirschman theory and psychographic analysis suggested that the only variable that was not significant to all the three elements measuring CCB was self-confidence and willingness of customers of the bank to complain. The findings of the study also proved that there are differences between complainers and non-complainers in terms of how they factor assertiveness, conserva- 
tism, self-confidence and willingness in the CCB. Customers seeking redress, exiting, or staying loyal were common to both groups as found in this study. The results of the study suggest that complaint management programmes should not only be geared towards complainers, but also should importantly consider non-complainers as well, as they are equally important to organizations and businesses. Since some of the customers might warn their friends or relatives of their dissatisfaction or stop patronizing the services of the organization.

In general, the findings of this study are not very different from previous studies, but this current paper has made several important contributions by analyzing psychographic factors and Hirschman's theory, predicting CCB of complainer and non-complainer utilizing assertiveness, conservatism, self-confidence and willingness as well as establishing statistical differences between these groups in a single study. The findings of the study have implications for marketing literature, practitioners, scholars and researchers in Ghana as well as the African continent in understanding and acknowledging the importance of psychographic factors of CCB in banking as one of the contributions of this paper.

However, while this study makes some useful conceptual and managerial contributions to current knowledge there are still certain methodological limitations. Firstly, the sample size might not be adequate to infer to all Ghanaian-banking consumers. Secondly, data collection was limited to only customers of public banks in the capital. It is suggested that this study can be taken countrywide in order to include a larger sample size.

\section{References}

1. Ajzen, I., \& Fishbein, M. (1980). Understanding attitudes and predicting social behavior. New Jersey: Englewood Cliffs, Prentice-Hall.

2. Atalik, O. (2007). Customer complaints about airlines service: A preliminary study of Turkish frequent flyers. Management Research News, 30(6), 409-419. http://dx.doi.org/10.1108 /01409170710751908

3. An, K., Hui, M., \& Leung, K. (2001). Who should be responsible? Effects of voice and compensation on responsibility attribute, perceived justice, and post-complaints behaviours cross cultures. International journal of Conflict Management, 2(4), 350-364. http://dx.doi. org/10.1108/eb022863

4. Azml, M., Zarina, A. M., \& Nur, L. K. (2015). Investigating the relationship between knowledge and complaints behaviour among Motor Vehcile Repairs consumers in Shah Alam, Malaysia. (Ed. 1). Global Journal of Business and Social Science Review, 2, 46-53.

5. Barnes, J., \& Kelloway, K. (1980). Consumerists: complaining behaviour and attitudes toward social and consumers issues. Advances in Consumer Research, 7(1), 329-334.

6. Bearden, W. (1983). Profiling consumers who register complaints aganist auto repairs services. The Journal of Consumer Affairs, 17, 315-335.

7. Bearden, W., \& Oliver, R. (1985). The role of public and private complaining in satisfaction with problem resolution. The Journal of Consumer Affairs, 19, 222-240. http://dx.doi. org/10.1111/j.1745-6606.1985.tb00353.x 
8. Bearden, W., \& Teel, J. (1983). Selected determinants of consumer satisfaction and complaints reports. Journal of Consumer Research, 20(1), 1173-1182. http://dx.doi. $\operatorname{org} / 10.2307 / 3151408$

9. Bearder, W., \& Mason, J. (1984). An investigation of influences on consumer complaints reports. Advances in Consumer Research, 11, 490-495.

10. Blodgett , J., Granbois, D., \& Walters, R. (1993). The effects of perceived justice on complaints' negative word-of-mouth behaviour and repatronage intentions. Journal of Retailing, 69(4), 399-428. http://dx.doi.org/10.1016/0022-4359(93)90015-b

11. Cheng, S., Lam, T., \& Hsu, C. (2006). Nagetive word-of-mouth communication intention: An application of the theory of planned behaviour. Journal of Hospitality and Tourism Research, 30, 95-116. http://dx.doi.org/10.1177/1096348005284269

12. Cho, Y., Im, I., Hitz, R., \& Fjermestad, J. (n.d.). The effects of Post-purchase Evaluation factors ofonline Vs offline customer complaining behaviour: Implications for customer loyalty. Advances in Consumer Research, 29, 2002. http://dx.doi.org/10.1109/hicss.2002.994162

13. Coopersmith, S. (1967). The Antecedents of self-esteem. Freeman, New York. http://dx.doi. org $/ 10.2307 / 2092806$

14. Cornell, T., Bleigh, A., \& Babakus, E. (1991). Complaints behaviour of Mexican American Consumers to a Third party. Journal of Consumer Affair, 25(1), 1-18. http://dx.doi. org/10.1111/j.1745-6606.1991.tb00278.x

15. Crie, D. (2003). Consumer complaints behaviour. Taxonomy,typology and determinants towards a unified ontology. Database marketing and Consumer Strategy Management, 11(1), 60-79. http://dx.doi.org/10.1057/palgrave.dbm.3240206

16. Davidow, M., \& Dacin, P. (1997). Understanding and influencing consumer complaint behaviour: improving organizational complaints management. Journal of Advances in consumer research, 24, 450-460.

17. Day, R. (1984). Modeling choices among alternative response to dissatisfaction. Advance in Consumer Research, 11, 496-499.

18. Day, R. L., \& Landon Jr, E. L. (1976). Collecting comprehensive consumer complaining data by survey research. Advance in Consumer Research, 3(1), 263-268.

19. Day, R. L., \& Landon, E. L. (1977). Toward a theory of consumer complaining behaviour. In: A.G Woodsie, J.N Sheth, \& P.D. Bennet (Ed). Consumer and industrial buying behaviour, 425-437.

20. Diamatopoulos, A., \& Siguaw, J. (2000). Introducing LISREL. London: Sage. http://dx.doi. org/10.1108/03090560310465206

21. Donoghue, S., \& De Klerk, H. M. (2006). Dissatsfied consumers' complaint behaviour concerning product failure of major electrical household appliances- a conceptual framework. Journal of Family Ecology and Consumer Science, 34, 41-55. http://dx.doi. org $/ 10.4314 /$ jfecs.v34i1.52882

22. Fornell, C., \& Wernerfelt, B. (1987). Defensive marketing strategy by consumer complaint management: A theoretical analysis. Journal of Marketing Research, 24(4), 337-346. http:// dx.doi.org/10.2307/3151381 
23. Gilly, M., \& Gelb, B. (1982). Post-purchase consumer processes and the complaining consumer. Journal of Consumer Research, 9(3), 323-328. http://dx.doi.org/10.1086/208927

24. Hair, J., Anderson, R., Tatham, R., \& Black, W. (1995). Multivariate data analysis. (4 ed.). New Jersey: Prentice-Hall Inc. http://dx.doi.org/10.2307/2348783

25. Heung, V., \& Lam, T. (2003). Customer complaints behaviour towards hotel restaurant services. International Journal of Contemporary Hospitality Management, 15(5), 283-289. http:// dx.doi.org/10.1108/09596110310482209

26. Hirschman, A. (1970). Exit, Voice and Loyalty: Responses to decline in firms, organizations and state. Cambridge: Cambridge, MA Havard University Press.

27. Hui, M., \& Au, K. (2001). Justice perceptions ofcomplaints handlin: A cross-cultural comparison between PRC and Canadian customers. Journal of Busines Research, 52(2), 161173. http://dx.doi.org/10.1016/s0148-2963(99)00068-5

28. Homburg, C., \& Furst, A. (2005). How organizational complaint handling drives customer loyalty: An analysis of the mechanistic and organic approach. Journal of Marketing, 63(3), 95114. http://dx.doi.org/10.1509/jmkg.69.3.95.66367

29. Iyiola, O., \& Ibidunni, O. (2013). The Relationship between complaints, emotion, anger and subsequent behaviour of customers. Journal of Humanities and Social Science, 17(6), 34-41. http://dx.doi.org/10.9790/0837-1763441

30. Jacoby, J., \& Jaccard, J. (1981). The source meaning and validity of consumer complaining behaviour: A psychological review. Journal of Retailing, 57(3), 4-24. http://dx.doi.org/10.1016/ s0969-6989(97)00013-1

31. Kau, A., \& Loh, E. (2006). The effects of service recovery on consumer satisfaction: A comparison between complaints and non-complaints. Journal of Service Marketing, 20(20), 101-111. http://dx.doi.org/10.1108/08876040610657039

32. Keng, K., \& Liu, S. (1997). Personal values and complaints. Journal of Retailing and Consumer Service, 4(2), 89-97. http://dx.doi.org/10.1016/s0969-6989(96)00019-7

33. Keng, K., Richmond, D., \& Han, S. (1995). Determinants of consumer complaints behaviour: A study of Singaporan consumers. Journal of International Consumer Marketing, 8(2), 59-76. http://dx.doi.org/10.1300/j046v08n02_05

34. Kim, C., Kim, S., Im, S., \& Shin, C. (2003). The effects of attitude and perceptions on consumer complaint intentions. Journal of Consumer Marketing, 20(4), 352-371. http://dx.doi. org/10.1108/07363760310483702

35. Kirkbir, F., \& Cengiz, E. (2007). Do frontline staff's psychographic attributes and perception of organizational factors affect service recovery performance? Innovative Marketing, 3(4), 21-29.

36. Komunda, M., Kibeera, F., Munyoki, J., \& Byarugaba, J. (2015, June). Improving customer complaining behaviour for loyalty in the service sectir: a case of mobile telephone companies in Uganda. African Journal of Business Management, 9(12), 521-530. http://dx.doi. org/10.1108/14637151211215028

37. Landon, J. (1980). The direction of consumer complaint research. Advances in Consumer Research, 7(1). http://dx.doi.org/10.1086/jcr.1980.7.issue-1 
38. Lau, G., \& Ng, S. (2001). Individual and situation factors influencing negative word-ofmouth behaviour. Canadian Journal of Administrative Science, 18(3), 163-178. http://dx.doi. org/10.1111/j.1936-4490.2001.tb00253.x

39. Liu, J., Kang, J., Bai, Y., \& Zhang, X. (2006). The Study of customer complaints management based on system dynamic: modelling and simulation proceedings. Fifth international conference on macbine learning and cybernetic, dalian. http://dx.doi.org/10.1109/ icmlc.2006.258340

40. Liu, R., \& McClure, P. (2007). Recognizing cross-cultural differences in consumer complaint behaviour and intentions: An empirical exmination. Journal of Consumer Marketing, 18(1), 54-74. http://dx.doi.org/10.1108/07363760110365813

41. Marsh, H., Hau, K., \& Wen, Z. (2004). In Search Golden Rules: Comment on Hypothesis-Testing Approaches to Setting Cutoff Values for Fit Indexes and Dangers in Overgeneralizing Hu and Bentler's Findings "Structural Equation Modelling. 11(3), 320 341. http://dx.doi.org/10.1207/s15328007sem1103_2

42. Morganosky, M., \& Buckley, H. (1987). Complaint behaviour: analysis by demographics lifestyle and consumer values. Advances in Consumer Research, 14(1), 223-226.

43. Ndubisi, N., \& Tam, Y. (2006). Complaint behaviour of Malaysian consumers. Management Research News, 29(2), 65-76. http://dx.doi.org/10.1108/01409170610645457

44. Nimako, S. (2012). Customer dissatisfaction and complaining responses towards mobile telephony services. The African Journal of Information System, 4(3).

45. Nimako, S., \& Mensah, A. (2014). Exploring customer dissatisfaction/ satisfaction and complaining responses among Bank customers in Ghana. International Journal of Marketing Studies, 6(2). http://dx.doi.org/10.5539/ijms.v6n2p58

46. Norazah, M. (2010). Dissatisfaction attributions and complaining behaviour of public library user. Information Management and Business Review, 25, 43-62.

47. Nunnally, J. C., \& Bernstein, I. H. (1994). Psychometric theory. (3rd. Ed.) http://dx.doi. org/10.1177/014662169501900308

48. Ofori-Okyere, I., \& Kumadey, G. (2015). An Assessement of Service Failure and Customer Complaints Management in the delivery of Health Care in the Municipal Hospital in Ghana. International Journal and Marketing Management, 3(1), 32-42.

49. Oh, D. (2003). Complaining behaviour of public users in South Korea. Library \& Information Science Research, 1(1), 28-39. http://dx.doi.org/10.1016/s0740-8188(02)00165-2

50. Oliver, R. (1980). A cognitive model of the antecedents and consequence of customer satisfaction. Journal of Marketing Research, 17, 460-469. http://dx.doi.org/10.2307/3150499

51. Oliver, R. (1997). Satisfaction: A behavioural perspective on the consumer. New York: The McGraw-Hill Companies .

52. Onyeaso, G. (2007). Are customers' dissatisfaction and complaint behaviour positively related? Empirical test. Journal of American Academy of Business, 11(1), 18-24. 
53. Petzer, D. (2012). Service failure, service recovery,customer complaints behaviour, attitude towards complaining likelihood of voicing a complaint, banking, domestice airlines, restaurant. Southern African Buisness Review, 16(2), 1-23. http://dx.doi.org/10.5897/ ajbm11.1000

54. Phau, I., \& Sari, R. (2004). Engaging in complaint behaviour: An Indonesian perspective. Marketing Intelligence and Planning, 22(4), 407-426. http://dx.doi.org/10.1108/0263450041054 2770

55. Richins, M. (1979). Consumer complaining process: A comprehensive model. In R.L Day \& H. Keith (Eds), New dimensions of consumer satisfaction and complain behaviour. Bloomington, IN: Indiana University Press.

56. Richins, M. (1983). Negative word-of-mouth by dissatisfied consumers: A pilot study. Journal of Marketing, 47, 68-78. http://dx.doi.org/10.2307/3203428

57. Richins, M. (1987). A multivariate analysis of responses to dissatisfaction. Journal of the Academy of Marketing Science, 15(3), 24-31. http://dx.doi.org/10.1007/bf02722168

58. Richins, M., \& Verhage, B. (1985). Seeking redress for customer dissatisfaction: the role of attitude and situational factors. Journal of Consumer Policy, 8(1), 29-44. http://dx.doi. org $/ 10.1007 /$ bf00380281

59. Sanes, C. (1993). Complaints are hidden treasures. The Journal for Quality and Participation, 16, $78-83$

60. Sheth, J., Mittal, B., \& Newman, B. (1999). Customer behaviour: consumer behaviour and beyond. Fort Worth,TX Dryden Press. http://dx.doi.org/10.1362/147539202323071254

61. Sheth, J., Newman, B., \& Gross, B. (1991). Consumption values and market choices. Theory and applications. Cincinnati: South-Western Publishing Co. http://dx.doi.org/10.2307/3172719

62. Singh, J. (1990). Voice,exit and negative word-of-mouth behaviour: An investigation across three service categories. Journal of the Academy of Marketing Science, 18(1), 1-15. http://dx.doi. org $/ 10.1007 /$ bf02729758

63. Singh, J., \& Wilkes, R. (1996). When consumers complain: A path analysis of the key antecedents of consumer complaint response estimate. Journal of the Academy of Marketing Science, 24(4), 350-365. http://dx.doi.org/10.1177/0092070396244006

64. Stephen, N., \& Gwinner, K. (1998). Why don’t some people complain? A cognitive-emotive process model of consumer complaint behaviour. Journal of Academy of Marketing, 26(3), 172 189. http://dx.doi.org/10.1177/0092070398263001

65. Sujithamrak, S., \& Lam, T. (2005). Relationship between customercomplaint behaviour and demographic charateristics: A Study of Hotel Restaurants' Patrons. Asia Pacific Journal of Tourism Research, 10(3), 289-307. http://dx.doi.org/10.1080/10941660500309697

66. Wysocki, A., Kepner, K., \& Glasser, M. (2001). Customer complaints and types of customers. Retrieved from Department of Food and Resources Economics, Institute of Food and Agricultural Science. 
67. Yuksel, A., Kilinc, U., \& Yuksel, F. (2006). Cross-national analysis of hotel customers' attitudes toward complaining and their complaining behaviour. Tourism Management, 27(1), 11-24 http://dx.doi.org/10.1016/j.tourman.2004.07.007

\section{Contact Information}

Alexander Preko (PhD)

University of Professional Studies, Accra

Department of Marketing

E-mail: alexander.preko@upsamail.edu.gh

Samuel Kwami Agbanu (PhD)

University of Professional Studies, Accra

Department of Marketing

E-mail:kwamiagbanu@gmail.com 